Nadwa : Jurnal Pendidikan Islam

Vol. 12, Nomor 2 Tahun 2018

Accredited by Ristekdikti based on Decree No. 51/E/KPT/2017

\title{
Model of Religious Culture Education and Humanity
}

\author{
Muhammad Luthfi Abdullah \\ Universitas 17 Agustus 1945 Cirebon, Indonesia \\ mluthfiabdullah@untagcirebon.ac.id
}

\author{
Akhmad Syahri \\ Institut Agama Islam Negeri Salatiga, Indonesia \\ akhmadsyahri90@iainsalatiga.ac.id
}

\begin{abstract}
This study aims to find out how the model of religious cultural education to create human character. This study uses a qualitative method. The research subjects were students at the Darut Tauhid Islamic boarding school in Bandung. The results of the study show that there are 8 (eight) religious cultures implemented in education and become a spirit to form human values, namely TSP (Resistant to littering, storing garbage in its place, picking up garbage insha Allah blessing); Bebaskomiba (Messing, Wet-Drying, DirtyCleaning, Leaning, Dangerous)); three $\mathrm{M}$, five $\mathrm{K}$, profit concept, five S, five don't, seven B.

Keywords: Education Model; Religious Culture; Islamic Humanity Value; Program Pesantren Mahasiswa; Daarut Tauhiid

Abstrak

Penelitian ini bertujuan untuk mengetahui bagaimana model pendidikan budaya berbasis agama untuk membentuk nilai-nilai kemanusiaan. Penelitian ini menggunakan metode kualitatif. Subjek penelitiannya adalah mahasiswa di pesantren Darut Tauhid Bandung. Hasil penelitian menunjukkan bahwa ada 8 (delapan) budaya agama yang diimplementasikan dalam pendidikan dan menjadi semangat untuk membentuk nilai-nilai kemanusiaan yaitu TSP (Tahan dari buang sampah sembarangan, Simpan sampah pada tempatnya,Pungut sampah insya Allah berkah); Bebaskomiba (Berantakan-rapikan, Basahkeringkan, Kotor-bersihkan, Miring-luruskan, Bahaya-amankan); tiga M, lima $K$, konsep untung, lima $S$, lima jangan, tujuh $B$.
\end{abstract}

Kata Kunci: Model Pendidikan; Budaya Agama; Nilai Kemanusiaan Islam; Program Pesantren Mahasiswa; Daarut Tauhiid

IS SN 1979-1739 (P) ; ISSN 2502-8057 (E).

6) 2018 Nadwa : Jurna1 Pendidikan Islam | UIN Walisongo.

Accredited by Ristekdikti bas ed on Decree No $51 / E / K P T / 2017$

http://joumal.walisongo ac.id/index.php/nadwa 


\section{Introduction}

The problem of education in Indonesia is that there are many behaviors that reduce human dignity. Corruption has made Indonesia a part of the most corrupt country in the world 1. Corruption is a heavy action in violating humanity values. Besides that, sexual harassment is also the same violation. BKKBN survey (Badan Kependudukan dan Keluarga Berencana Nasional) in 2008 stated $63 \%$ of teenagers in big cities in Indonesia had premarital sex 2. This is not in line with the objectives of Islamic Education in schools3. Islam as a religion that raises human values has been evident from the history of Arab life changes in times of jahiliya. One of them is when a newborn girl baby is buried alive, Islam abolished such atrocities4.

Humanism is one of the schools of philosophy, departs from the spirit for a better human lifes. This study does not explain how the definition of humanism in depth, but how the values of humanism itself are more applied in life. One of the values discussed here is liberty. However, what is meant here is not liberty without any limitation. Islam is present to provide a more

1 Fazzan, "Korupsi Di Indonesia Dalam Perspektif Hukum Pidana Islam," Jurnal Ilmiah ISLAM FUTURA 14, no. 2 (Februari): 147, http://dx.doi.org/10.22373/jiif.v14i2.327.

2 "Analisis Faktor Penyebab Perilaku Seksual Pranikah Pada Remaja Di Desa Wedomartani Sleman Yogyakarta," Jurnal Ners Dan Kebidanan Indonesia 4, no. 1 (June 2016): http://dx.doi.org/10.21927/jnki.2016.4(1).39-43.

3 Muhammad Luthfi Abdullah, "Efektivitas Penerapan Metode Qişşatu Al-Qur'Ānī Untuk Meningkatkan Akhlak Mulia Siswa Kelas IV SD Cirebon Islamic School (CIS) Full Day," Al-Tadzkiyyah: Jurnal Pendidikan Islam 9, no. 1 (2018): 154.

4 Q.S. 16:58-59 and Q.S. 81:8-9

5 Mustaghfiroh, "Implementasi Nilai-Nilai Humanisme Islam Melalui Metode Pembelajaran Dalam Pendidikan Agama Islam Di Smp Al-Hikmah Karangmojo Gunungkidul" (Skripsi, Universitas Islam Negeri Sunan Kalijaga Yogyakarta, 2016), 3, http://digilib.uin-suka.ac.id/21675/2/11410122_BABI_IV-atau-V_DAFTAR-PUSTAKA.pdf. 
comprehensive view so that the liberty interpreted will not destroy human life itself.

The essence of education is not only about teaching (transfer of knowledge), but more than that is educating to have morals and humanistic values. Therefore, for students to have morals and to have humanistic values which in fact as part of Islamic teachings, religious culture must be programmed and built immediately in every educational institution.

The religious culture in question is a set of religious values that underlie behavior, traditions, daily habits, and symbols practiced by all stakeholders in each educational institution. Therefore, the embodiment of culture does not just appear, but through the process of civilizing. Such as culture when worshiping to Allah subhanahu wa ta'ala, fellow human beings, and good culture towards nature in a way that has been determined by religion with an atmosphere of calm, clean, and wisdom. Thus, religious culture relates to a set of actions that are manifested in behavior, traditions, daily habits and symbols that are practiced based on religious values in an educational institution.

Muhammad Fathurrahman revealed that religious values can be divided into several things, including; the value of worship, ruhul jihad values, moral values and discipline, exemplary, amanah and sincere. First, the value of worship, word worship is the Indonesian language which comes from Arabic, that is from masdar 'abada. 'Abada is interpreted in terms of being solemn to God, obedient to carrying out His commands and go away from His prohibitions. So worship is human obedience to God which is implemented in daily activities such as prayer, fasting, charity, etc. Secondly, ruhul jihad means a soul that encourages people to work or struggle seriously. This is based on the purpose of human life, namely hablum minallah, hablum min al-nas, and hablum min al-alam. With the commitment of ruhul jihad, so the self- 
actualization and performance are always based on striving and earnest efforts. Third, moral values and discipline. Morals are the plural 'of khuluq, meaning temperament, character, shame, and custom. According to Quraish Shihab, "Morals even though derived from Arabic (which usually means character, temperament, habits and even religion), but words like that are not found in the Qur'an. The word contained in the Qur'an is the word khuluq, which is a mufrad form of the moral word. While discipline is manifested in human habits when carrying out routine worship every day. All religions teach a practice that is carried out by its followers as a routine which is a means of the relationship between human with His creation, and it's neatly scheduled. If humans carry out worship in a timely manner, then the discipline value is automatically embedded in the person. Then if it is carried out continuously it will become a religious culture. Fourth, exemplary value. These values are reflected in teacher behavior. Exemplary is a very important thing in education and learning. Even al-Ghazali advised, as quoted by Ibn Rushd, to every teacher to always be an example and center of attention for his students. He/she must have high charisma. This is an important factor that must be in a teacher. Fifth, amanah and sincerely values. Etymologically, amanah means trustworthy. In the concept of leadership, amanah is also called responsibility. In the context of education, the amanah value must be held by all managers of educational institutions, both heads of educational institutions, teachers, education personnel, staff, and committees at the institution, as well as students. While sincerely etymologically means clean from a mixture of dirty things. In general, sincerely means free of self-interest in everything that is done.6

6 Muhammad Fathurrohman, "Kategorisasi Nilai Religius," Wordpress, Kategorisasi Nilai Religius (blog), November 12, 2012, 
Program Pesantren Mahasiswa (PPM) is a one-year Islamic boarding school student program at Daarut Tauhiid. This program only applies to students living in the area around Bandung, West Java, Indonesia. This education program is oriented towards the cultivation of faith, soft skills development, and Islamic life habits. In training students' soft skills, PPM routinely holds big events every year, namely "Pekan Parade Muslim" (Pepamu) and also a meeting of PPM alumni from various regions, namely "Keluarga Besar PPM" (KBPPM).

PPM students are given basic education during the orientation period in the form of the introduction of Daarut Tauhiid Culture. This culture is part of the religious culture that will be the study in this research. Previous research has shown how this religious culture is applied to improve the quality of education 7 and how this culture is implemented in Islamic Religious Education8. This study examines how religious culture is applied as an educational model in shaping Islamic humanistic values.

This study uses a qualitative approach. A qualitative approach is a type of research whose findings are not obtained through statistical procedures or other forms of calculation. This research attempts to understand and interpret the meaning of an interaction between human behavior in certain situations according to the author's own perspective.

https://muhfathurrohman.wordpress.com/2012/11/12/kategorisasi-nilaireligius/.

7 Muhammad Fathurrohman, "Pengembangan Budaya Religius Dalam Meningkatkan Mutu Pendidikan," Ta'allum 4, no. 1 (n.d.): 1-24, https://doi.org/10.21274/taalum.2016.4.1.19-42.

8 kristiya Septian Putra, "Implmentasi Pendidikan Agama Islam Melalui Budaya Religius (Religious Culture) Di Sekolah," Jurnal Kependidikan 3, no. 2 (n.d.): 14-32, https://doi.org/10.24090/jk.v3i2.897. 


\section{Model Based Religious Culture to Form Islamic Humanity Value}

1. Islamic Humanity Value

Definisi humanity very closely related to the reality of humanity itself and his different aspects. Below are four things related to human reality9.

First, humans are objective beings that are certainly different from other objective beings with their honor in freedom of choice, this means that their actions and behavior are the results of consideration and ability, even though they are relative. Second, humans are largely influenced by the surroundings, such as the physical environment, and other lives. Third, human life is a social life that naturally interacts with other human beings. Fourth, human beings are closely related to their creators, because the one who created them is Allah subhanahu wa ta'ala.

The Qur'an has emphasized important relationships so that harmony between religion and humanity occurs 10 .

Islam, the adherents are Muslims. Muslims are those who give themselves to Allah. When he surrenders himself to God he will receive the nature of humanity that God himself created for man. A human being is related to God, his own kind, nature, and the whole creation from that natural position. So, a human being's Islam is his humanity. The Holy Qur'an emphasizes the full alignment of religion and humanity11).

Allah subhanahu wa ta'ala, the Creator of the human being and the entire universe, is the only Able One to define the human being's characteristics. A human being's characteristic which related to God is a belief in God. Muslim believe in one God,

9 Sayyid Musa Sadr, "Islam, Humanity and Human Values," Ahlul Bayt World Assembly 11, no. 4 (2011): 2.

10 Qur'an Surah Ar-Rum: 30

11 Qur'an Surah Al-Baqarah: 137-138 
who has the Most Beautiful names and noblest qualities; One who neither begets nor was begotten. In Islam, it's all faith. The effect of this faith in knowing human values reflects the following points 12:

First, the great position of humanity is to take the responsibility in all major and minor works, overt and covert activities. Second, respect for human actions. The belief that all his efforts will not be in vain, will surely be seen and rewarded by Allah subhanahu wa ta'ala. Third, belief in all good or bad efforts will get a reward/punishment from Allah subhanahu wa ta'ala. This belief gives encouragement for someone to guard against actions that bring down human dignity and improve actions that can prosper human life. Fourth, people must pay attention to the role of repentance in the reinforcement of human effort, it's will keeping him away from despair and disappointment, and facilitating the making up of past errors.

\section{Religious Culture}

The term "culture" first came from the discipline science of social anthropology. Everything is included in the definition of culture is very broad in sense and meaning. The term of culture can be interpreted as the totality of patterns of behavior, art, beliefs, institutions, and all other products of human work and thought that characterize the condition of a society or population which transmitted together13.

Culture comes from Sanskrit, namely buddhayah, which is the plural form of buddhi (mind or reason) interpreted as matters relating to mind and human reason. In English, it is called culture, which comes from the Latin Colere word, which is processing or doing.

12 "Islam, Humanity and Human Values," 6-7.

13 J.P. Kotter J.L. Heskett, Dampak Budaya Perusahaan Terhadap Kinerja (Jakarta: Prehallindo, 1992), 4. 
Religion, comes from the Latin "religio", English; "Religion", Arabic "al-diin" or religion. Religiosity is the belief in God Almighty with the teachings of worship and obligations related to that belief 14 .

Religious culture is a set of religious values that underlie behavior, traditions, daily habits, and symbols practiced by society. Therefore culture is not only symbolic as reflected above but in it is full of values. Cultural manifestations do not just appear but through the process of civilization. Therefore religious culture is a culture that allows every citizen of the community to worship, relate to God in a way that has been determined by religion with an atmosphere of calm, clean, and wisdom. Thus religious culture relates to a set of actions that are manifested in behavior, traditions, daily habits and symbols practiced based on religion, in the context of society15.

\section{Result}

As explained in the description theory, that in this study there are four Islamic humanity values which are reflected in the religious culture Daarut Tauhiid and then applied in education.

1. Take humanitarian responsibility for great works and small works. For small works, there is a TSP culture which abbreviation from: "Tahan dari buang sampah sembarangan; Simpan sampah pada tempatnya; Pungut sampah isnya Allah sedekah". The students are taught to maintain cleanliness in terms of garbage. The most interesting thing is that there are monthly cleaning activities. This activity is carried out by students together by surrounding the place around the

14 Badan Pengembangan dan Pembinaan Bahasa, "Kamus Besar Bahasa Indonesia" (Kementrian Pendidikan dan Kebudayaan Republik Indonesia, 2016), https://kbbi.kemdikbud.go.id/entri/religiositas.

15 Muhaimin, Paradigma Pendidikan Islam (Bandung: Rosdakarya, 2001), 294. 
dormitory, then picking up trash when he finds it. The students were taught when they found trash on the road, then the garbage was taken and then dumped in the trash. This culture is applied not only in the pesantren environment but when they are outside it is also sought to keep practicing this culture. Besides that, there is a culture of BEBAS KOMIBA which abbreviation from BE (Berantakan-Rapihkan), BAS (BasahKeringkan), KO (Kotor-Bersihkan), MI (Miring ex. stuffLuruskan), BA (Bahaya-Amankan). This culture is very applied in dormitories. Especially when Friday's clean activities, the students are accustomed to practicing this culture. The hope is that students can practice this culture in their surroundings, at least in their own families. In addition, there is also a basic culture that encourages change in the environment, namely 3M: Mulai dari diri sendiri; Mulai dari hal yang kecil; Mulai saat ini. This culture is combined with the culture of $5 \mathrm{~K}$ (Kerja cerdas, Kerja tuntas, Kerja mawas, Kerja ikhlas) and also with the culture of $3 \mathrm{~S}$ (Semangat bersaudara, Semangat mencari solusi, Semangat maslahat bersama). In the application of the three cultures, it was applied in the activities of "Pekan Parade Muslim". This activity is also a form of responsibility for humanity on a broader (large) scale. This activity is held by students who are one of the da'wah media and a form of self-existence based on the implementation of worship to God and concern with the spirit of community service and the implementation of Islamic values gained during the program.

2. The belief that all the effort that is done will not be in vain, surely it will be seen and replied by Allah subhanahu wa 'ta'ala. This value is reflected in the culture of $5 \mathrm{~K}$ (Kerja cerdas, Kerja tuntas, Kerja mawas, Kerja ikhlas). The main thing is a sincere work culture. In familiarizing this culture, students are given the opportunity to take part in the service of mosque 
worshipers in Daarut Tauhiid. This activity was not forced and followed on the basis of the willingness of the students themselves. The activities carried out by him are tidying slipper, preparing food to break the fast, and other activities related to mosque worship services. In addition, there are also activities of sharing, charity, and benefit included in the activities of "Pekan Parade Muslim". This activity is a social activity free of charge such as blood donation, visits to orphans, free cupping, etc.

3. The belief in all good or bad endeavors will be rewarded/punished by Allah subhanahu wa 'ta'ala. This belief gives encouragement for someone to guard against actions that bring down human dignity and improve actions that can prosper human life. This kind of value is built from the "Konsep Untung" culture with a description: bila jadi amal kebaikan, bila jadi ilmu, bila bermanfaat, bila menambah silaturahim, bila menguntungkan orang lain. Then another culture is $7 \mathrm{~B}$ (beribadah dengan baik, benar, dan istiqomah; berakhlak baik; belajar tekun tiada henti; bekerja keras, cerdas, dan ikhlas; bersahaja dalam hidup; bantu sesama; bersihkan hati selalu). In implementing the culture the santri are accustomed to daily practice in the form of; Qur'an recitations, morning and evening dhikr, sunnah fasts, congregational prayers, etc. Besides that, there is also a $5 \mathrm{~S}$ culture (senyum, salam, sapa, sopan, santun).

4. People must pay attention to the role of repentance in the reinforcement of human effort, keeping him away from despair and disappointment, and facilitating the making up of past errors. The culture that emphasizes this value is "5 Jangan" such as Jangan panik; Jangan emosional; Jangan tergesa-gesa; Jangan larut mendramatisasi; Jangan putus asa. Then, the culter of 7B (as mentioned above) can be categorized in this value. In applying this culture, education is carried out, such 
as the existence of Mabit activities (Malam Bina Iman dan Taqwa), then the tahajud activities, and other activities.

\section{Conclusion}

The value of humanity in Islam is based on the nature of creation that has been given by God. This value is emphasized so that humans live their roles as caliphs on earth and also servants of Allah subhanahu wa ta'ala. In building this value, one of them is through education based on religious culture. Daarut Tauhiid as a modern Islamic boarding school that provides education services, one of the programs is a Program Pesantren Mahasiswa. In this program introduced the culture of Daarut Tauhiid which reflects religious culture. Through observations, interviews, and documentation that researchers do, these cultures indicate Islamic humanity values. These cultures such as:

1. TSP (Tahan dari buang sampah sembarangan, Simpan sampah pada tempatnya, Pungut sampah insya Allah sedekah)

2. BEBASKOMIBA (BE-berantakan-rapikan;BAS-basahkeringkan;KO-kotor-bersihkan;MI-miring-luruskan;BAbahaya-amankan)

3. 3M (Mulai dari diri sendiri; Mulai dari hal yang kecil; Mulai saat ini)

4. 5K (Kerja keras; Kerja cerdas; Kerja mawas; Kerja tuntas; Kerka ikhlas)

5. "Untung" concept (bila jadi amal kebaikan; bila jadi ilmu; bila bermanfaat; bila menambah silaturahim; bila menguntungkan orang lain)

6. 5S (Senyum; Salam; Sapa; Sopan; and Santun)

7. 5 "Jangan" (Jangan panik; Jangan emosional; Jangan tergesa-gesa; Jangan larut mendramatisasi; Jangan putus asa) 
8. 7B (Beribadah dengan baik, benar, dan istiqomah; Berakhlak baik; Belajar tekun tiada henti; Bekerja keras, cerdas, dan ikhlas; Bersahaja dalam hidup; Bantu sesama; Bersihkan hati selalu).

These cultures are familiarized in educational programs such as amalan yaumiyah; Pekan Parade Muslim activities; Sharing, charity, and useful activities; Mosque Worship Services Daarut Tauhiid, MABIT (Malam Bina Iman dan Taqwa) activities, Tahajud activities, and other activities.

\section{References}

Achmad Faqihuddin. "Internalisasi Nilai-Nilai Humanistik Religius Pada Generasi Z Dengan 'DesignFor Change.'” Jurnal Edukasia: Jurnal Penelitian Pendidikan Islam 12, no. 2 (n.d.): 263-84. http://dx.doi.org/10.21043/edukasia.v12i2.2471.

Badan Pengembangan dan Pembinaan Bahasa. "Kamus Besar Bahasa Indonesia." Kementrian Pendidikan dan Kebudayaan Republik Indonesia, Oktober 2016. https://kbbi.kemdikbud.go.id/entri/religiositas.

Creswell J. Riset Pendidikan. 5th ed. Yogyakarta: Pustaka Pelajar, 2015.

Departemen Agama Republik Indonesia 2007. Al-Quran Terjemah Per-Kata. (Penerjemah) Lajnah Pentashih Mushaf al-Qur'ān. Bandung: CV Cahaya Qur'an.

Fazzan. "Korupsi Di Indonesia Dalam Perspektif Hukum Pidana Islam." Jurnal Ilmiah ISLAM FUTURA 14, no. 2 (Februari):

147. http://dx.doi.org/10.22373/jiif.v14i2.327.

Huberman, A. M., Miles, M. B. Analisis Data Kualitatif. Jakarta: Universitas Indonesia Press, 1992. 
Imam Gunawan. "Metode Penelitian Kualitatif." n.d. http://fip.um.ac.id/wpcontent/uploads/2015/12/3_Metpen-Kualitatif.pdf.

J.L. Heskett, J.P. Kotter. Dampak Budaya Perusahaan Terhadap Kinerja. Jakarta: Prehallindo, 1992.

Kristiya Septian Putra. "Implmentasi Pendidikan Agama Islam Melalui Budaya Religius (Religious Culture) Di Sekolah." Jurnal Kependidikan 3, no. 2 (n.d.): 14-32. https://doi.org/10.24090/jk.v3i2.897.

Muhaimin. Paradigma Pendidikan Islam. Bandung: Rosdakarya, 2001.

Muhammad Fathurrohman. "Kategorisasi Nilai Religius." Wordpress. Kategorisasi Nilai Religius (Blog), November 12, 2012. https://muhfathurrohman.wordpress.com/2012/11/12/kat egorisasi-nilai-religius/.

. "Pengembangan Budaya Religius Dalam Meningkatkan Mutu Pendidikan." Ta'allum 4, no. 1 (n.d.): 1-24. https://doi.org/10.21274/taalum.2016.4.1.19-42.

Muhammad Luthfi Abdullah. "Efektivitas Penerapan Metode Qişşatu Al-Qur'Ānī Untuk Meningkatkan Akhlak Mulia Siswa Kelas IV SD Cirebon Islamic School (CIS) Full Day." Al-Tadzkiyyah: Jurnal Pendidikan Islam 9, no. 1 (2018): 153-65.

Mustaghfiroh. "Implementasi Nilai-Nilai Humanisme Islam Melalui Metode Pembelajaran Dalam Pendidikan Agama Islam Di Smp Al-Hikmah Karangmojo Gunungkidul." Skripsi, Universitas Islam Negeri Sunan Kalijaga Yogyakarta, $2016.2 \mathrm{http}$ ://digilib.uinsuka.ac.id/21675/2/11410122_BAB-I_IV-atauV_DAFTAR-PUSTAKA.pdf.

Sayyid Musa Sadr. "Islam, Humanity and Human Values." Ahlul Bayt World Assembly 11, no. 4 (2011). 
344 | Muhammad Luthfi Abdullah \& Akhmad Syahri

Sugiyono. Metode Penelitian Pendidikan. Bandung: Alfabeta, 2011.

Suwarsi. "Analisis Faktor Penyebab Perilaku Seksual Pranikah Pada Remaja Di Desa Wedomartani Sleman Yogyakarta." Jurnal Ners Dan Kebidanan Indonesia 4, no. 1 (June 2016): 39-43. http://dx.doi.org/10.21927/jnki.2016.4(1).39-43. 